\title{
Managerial Ability as a Mechanism for Creating Firm Value through Risk Management
}

\author{
RICHARD WIRATAMA \\ SUWANDI NG* \\ Atma Jaya Makassar University
}

\begin{abstract}
This study investigates the role of managerial ability on the creation of firm value which is tested directly and indirectly through risk management. This research model was built based on resource-based view theory dan stakeholder theory. The population in this study was all companies listed on the Indonesia Stock Exchange (IDX) in 2018-2020. The sample used in this study was 183 non-financial companies, which was selected by the purposive sampling method. This study uses documentary data, i.e., the annual report and financial statements. Path analysis was used to analyze the data, and the mediation hypothesis was analyzed using the Sobel mediation test. The results of this study indicate that 1). The managerial ability has a positive and significant impact on risk management; 2). The managerial ability has a positive and significant impact on firm value; and 3). The implementation of risk management can fully mediate the impact of managerial ability on firm value. The implications of this study are expected to provide theoretical implications for the development of science in the field of accounting and management regarding the factors that affect firm value. Implications practice of this research is as learning for companies and investors to consider the importance of risk management through managerial ability as a mechanism to create firm value.
\end{abstract}

Keywords: Managerial ability, risk management, firm value

Abstrak - Penelitian ini bertujuan untuk menginvestigasi peran kecakapan manajerial terhadap penciptaan nilai perusahaan yang diuji secara langsung dan tidak langsung melalui pengelolaan risk management. Model penelitian ini dibangun atas dasar resource based view theory dan stakeholder theory. Populasi dalam penelitian ini adalah seluruh perusahaan yang terdaftar di Bursa Efek Indonesia (BEI) pada periode 2018-2020. Sampel yang digunakan dalam penelitian ini adalah sebanyak 183 perusahaan non-keuangan, yang dipilih menggunakan metode purposive sampling. Penelitian ini menggunakan data dokumenter, yaitu laporan tahunan dan laporan keuangan. Analisis jalur digunakan untuk menganalisis data dan hipotesis mediasi dianalisis dengan menggunakan uji sobel. Hasil penelitian ini menunjukkan bahwa 1). Kecakapan manajerial memiliki dampak positif dan signifikan terhadap risk management; 2). Kecakapan manajerial memiliki dampak positif dan signifikan terhadap nilai perusahaan; dan 3). Penerapan risk management dapat memediasi dampak kecakapan manajerial terhadap nilai perusahaan. Implikasi penelitian ini diharapkan dapat memberikan implikasi teoretis bagi pengembangan ilmu 
pengetahuan dalam bidang akuntansi dan manajemen mengenai faktor yang berpengaruh terhadap nilai perusahaan. Implikasi praktik sebagai pembelajaran bagi perusahaan dan investor untuk mempertimbangkan pentingnya risk management melalui peran kecakapan manajerial sebagai mekanisme untuk menciptakan nilai perusahaan.

Kata Kunci: Kecakapan manajerial, risk management, nilai perusahaan

\section{Introduction}

The main purpose of a company is to make a profit and maximize the firm value. The company's value is essential because it describes the financial performance and is further a manifestation of the stakeholders' trust in the company since its establishment until now. The firm value is seen as an achievement and market confidence in the company's performance so that the company is considered to have good prospects (Nurhikmah and Setiany, 2020). Maximizing the value of the company means maximizing the stakeholders' wealth. In maximizing the prosperity of its stakeholders, the company will always strive to manage its business activities properly.

Companies in managing their business activities cannot avoid a risk (Malik and Simatupang, 2021). Risk is the effect of uncertainty on the goals of each company. This uncertainty should be appropriately managed. Risk management is a coordinated activity to direct and control organizations related to risk management (ISO 31000, 2018). Risk management carried out by the company properly will be able to prevent the realization of risks and reduce the negative impacts caused by risks. Risk manage ment can help companies maintain access to capital markets and other resources to implement business strategies and plans. Risk management is part of an overall business strategy intended to protect and increase stakeholder value (Hoyt and Liebenberg, 2011).

The complexity of risk can come from internal or external companies that can interfere with company profitability, so companies that do not have good risk management will have difficulty protecting the value of their companies. ISO 31000 (2018) states that the benefits of implementing risk management, if carried out 
effectively, will create and protect company value and support the achievement of company goals.

Risk management is essential for the company's business, especially in today's dynamic environment, which causes increasingly high challenges and uncertainties every company faces. This makes companies need to act more wisely by managing the risk exposures they face, and in the long term, a holistic mitigation plan is needed. This needs to be done to ensure the company's resilience in the future so that the company's value can be protected so that there is no decline in public trust (distrust) in the company.

The Asia Risk Report states that on a scale of 1 to 5, Indonesia has a score of 2 in the risk management rate of maturity, of which 5 is the highest score. This indicates that the application of risk management by companies in Indonesia is still relatively low. The phenomenon of risk management that leads to a decrease in the trust and prosperity of stakeholders has occurred in Indonesia. One case that reflects this is PT. Asuransi Jiwasraya, which is one of the red-plated insurance companies in Indonesia. PT. Asuransi Jiwasraya began to be raised to the public in early February 2019. The company delayed payment of insurance claims from customers of their JS Saving Plan products by Rp. 802 billion.

The Audit Board of the Republic of Indonesia (BPK) identified the potential liquidity risk for failure to pay customer claims. In the audit report, BPK has detected an unreasonable investment, namely the purchase of shares in companies with poor fundamentals and are not performing well. In addition to the identification of BPK, the Financial Services Authority of the Republic of Indonesia (OJK) supervisory body has also sent a similar warning signal through its supervision of PT. Asuransi Jiwasraya, where OJK has seen the possibility of defaulting on customer claims for a long time, where claim payments can still be covered from new customer premium deposits.

This indication of high risk through BPK examination and supervision by the OJK was not considered directly by the management of PT. Asuransi Jiwasraya, where early preventive measures are not taken. From this phenomenon, it can be seen that the implementation of risk management on the company's risks, such as liquidity risk, 
financial risk, and legality risk at PT. Asuransi Jiwasraya is not yet optimal and effective.

Negative impacts can arise for a company if the risks to the company are not identified and handled early, which can lead to market concerns and other risks, such as reputational risk and trust from the public and foreign investors to companies in Indonesia. Therefore, applying risk management is very important for companies to be managed by competent company resources. This is in line with the resource-based view theory, which views that the company's resources and capabilities are essential because they are the basis or basis of the company's competitiveness and performance (Wernerfelt, 1984).

Resources owned by a company can come from internal and external parties and can be in the form of tangible and intangible assets that can increase the value of a company. Managers as internal resources who manage the company are directly responsible for managing existing risks. In its management, a manager needs an ability so that risk can be minimized and predicted. Managerial ability can identify opportunities that allow the company to further while mitigating risks that could affect the firm's value.

Managerial ability is an essential factor in risk management. A company's progress depends on how managers manage the company; therefore, companies need capable managers (Wati et al., 2020). A capable manager is considered to have high ability and integrity as well as experience so that managers can make the right decisions for the betterment of the company. The research of Andreou et al. (2016), Yung and Chen (2018), Wati et al. (2020) found that capable managers are more likely to be able to carry out risk management optimally.

Managers become people stakeholders trust to manage the company and develop the company, which will add value to the company. Managers with high ability can organize, coordinate, and mobilize all resources effectively and efficiently to achieve the goal of increasing firm value. La'bi et al. (2018) stated that managers who can manage and design business processes efficiently would make the right decisions to maximize firm value. 
Research by Ng and Daromes (2016); La'bi et al. (2018); Chuah and Foong (2019); Gong et al. (2019); and Bhutta et al. (2021) find that overall managerial ability plays a vital role in increasing firm value. The experience and insight possessed by a manager will improve managerial ability to increase the firm value further. However, Afia and Arifah (2020); Dewiruna et al. (2020) found that the level of managerial ability did not determine the firm value. This is because managers with high managerial ability may not necessarily be able to mobilize company resources effectively and efficiently, such as the inability of managers to report goodwill and other intangible things that must be reported in the annual report. Capable managers have better communication ability that helps build the trust of market participants by effectively portraying the positive aspects of the company's future value at a minimum level of manageable risk.

Implementing effective risk management in the company will significantly assist the company in increasing the trust and prosperity of its stakeholders. Risk management research on firm value still causes much debate and has inconsistent results. Hoyt and Liebenberg (2011) stated that the application of risk management positively influences firm value. The empirical results state that the application of risk management will increase the company's value by $3.6 \%-17 \%$. This is supported by research conducted by Pamungkas (2019); Supriyadi and Setyorini (2020); Saeidi et al. (2020); Dinoyu and Septiani (2020); Yulinda et al. (2020); Sedani and Ayu (2021), which show that the company's risk management policies have a positive influence on firm value. Companies that can carry out good risk management are more attractive to investors because of the guarantee that the company has a good strategy to maximize profits. While the opposite results were found by the research of Siregar and Safitri (2019); Fadilah and Afriyenti (2020); Emar and Ayem (2020); Lestari et al. (2020); Fadhilah and Sukmaningrum (2020), which stated that the application of risk management has no significant effect on firm value. This is because risk management is only applied to high-risk companies and only to comply with applicable regulations.

Based on the phenomena and research results found above, there are still differences in research results from previous researchers. This motivates researchers to investigate further the effect of implementing company risk management based on ISO 
31000 in 2018 through company resources, namely managerial ability, on firm value creation.

This motivates researchers to investigate further the effect of managerial ability on the implementation of risk management; the effect of managerial ability on firm value; the effect of the implementing of risk management on the firm value; and the effect of implementing company risk management based on ISO 31000 in 2018 through company resources, namely managerial ability on firm value creation.

This study develops the previous research model by Pamungkas (2019) by adding a managerial ability variable as part of the company's resources that carry out risk management to increase the firm value. A manager who has more ability considers the costs and benefits of managing company risk through risk management because it will impact company goals. In addition, this study uses the perspective of the latest framework of risk management which is different from previous research, namely ISO 31000 (2018), which provides a framework for applying risk management in creating and protecting firm value.

This research is essential to study by looking at the current phenomenon related to risks that contain uncertainty in the company. A company requires an effective risk management application to control existing risks through the skills of a manager in running the company so that it will be able to increase the company's value for the prosperity of stakeholders.

This research is expected to contribute theoretically and practically. Theoretically, it is expected to enrich references for future research in the study literature on the influence of the role of managerial ability in creating firm value through risk management based on resource-based view theory and stakeholder theory. Practically, this research contributes to the company's management as a practice development in organizational life, where the results of this research are expected to provide input for the company's management to be used as motivation in improving their managerial ability, especially in terms of risk management to increase the value of the company. For investors and potential investors, this research can be used as a guide in making investment decisions. Investors and potential investors can choose companies that 
implement risk management effectively so that their investments can be safe. For regulators, as a reference or input to continue to improve guidelines related to the implementation of risk management to assure stakeholders against corporate uncertainty that will occur in the future and encourage the creation of firm value.

\section{Theoretical Framework and Hypothesis Development}

\subsection{Resource-Based View Theory (RBV Theory)}

The resource-based view theory (RBV theory) proposed by Wernerfelt (1984) views that the company's resources and capabilities are essential because they are the basis of its competitiveness and performance. The basic assumption of the RBV theory is how a company can compete with other companies by managing the company's resources in question by the company's ability to achieve the company's competitive advantage.

Barney (1991) developed the concept of the resource-based view, which has a vital role in strategic management. The concept states that an organization will achieve a sustainable competitive advantage if it has valuable, unique, rare, and difficult to imitate. RBV theory states that the company's competitive advantage can be achieved when it has good management of its resources. The resource-based approach emphasizes the importance of internal resources to achieve sustainable competitive advantage. This perspective states that company performance is a function of how well managers build their organizations in handling valuable, rare, difficult to imitate, and difficult to replace.

This study uses resource-based view theory because, concerning the capability of

the company's resources, it is in the form of managerial ability possessed by management as the manager of the company's operational activities related to the company's risk (risk management), which allows the company to create and increase firm value.

\subsection{Stakeholder Theory}

Stakeholder theory (Freeman, 1984) suggests that stakeholders are groups or individuals who can influence and or be influenced by the activities carried out by the 
company to achieve the company's goals. Stakeholders are a group of individuals who have an interest in the decisions and activities of the company. Stakeholder theory states that directors or managers must pay attention to broader parties or groups than just shareholders or capital owners in corporate governance. Furthermore, the support obtained from stakeholders for the company influences the existence of the company itself.

$\mathrm{Ng}$ and Daromes (2016) argue that in the perspective of stakeholder theory, stakeholders will seek to improve managerial ability to use insights and any information to create better firm value, which in essence, the stakeholder perspective is to create a higher level of welfare for stakeholders' interests involved in the firm's value creation system. The stakeholder theory proposed by Freeman (1984) explains that a manager is obliged to run the company's operations and meet the company's needs and provide additional value for investors and meet the needs of other company stakeholders. Therefore, managers will use their ability to increase the company's value to provide prosperity for stakeholders.

This study uses stakeholder theory because stakeholder theory can be used as a basis for increasing prosperity for stakeholders. Through effective risk management by capable managers, companies should pay attention to the interests of stakeholders who will create and protect value for the company.

\subsection{Theoretical Framework}

Risk management berperan sebagai variable intervening dalam penelitian ini. Nilai perusahaan berperan sebagai variabel dependen. Kecakapan manajerial sebagai pihak yang akan berpengaruh terhadap nilai perusahaan. Model penelitian ini menggunakan teori RBV (Resource Based View Theory) dan teori Stakeholder (Stakeholder Theory). RBV theory menjelaskan pengaruh kapabilitas sumber daya dari kecakapan manajerial melalui pengelolaan risk management dan pengaruhnya terhadap penciptaan dan perlindungan nilai perusahaan. Stakeholder theory sendiri membantu mempertegas penciptaan nilai perusahaan yang menandakan kemakmuran dari para stakeholder yang 
dapat diperoleh melalui faktor risk management yang dilakukan dengan baik oleh manajerial yang cakap.

Risk management acts as an intervening variable in this study. The firm value acts as the dependent variable. Managerial ability as a party that will affect the firm value. This research model uses RBV theory (resource-based view theory) and stakeholder theory. RBV theory explains the influence of resource capability from managerial ability through risk management and its effect on the creation and protection of firm value. Stakeholder theory itself helps to emphasize the creation of firm value which signifies the prosperity of the stakeholders that can be obtained through risk management factors carried out well by capable managers.

Resource-based view theory (Wernerfelt, 1984) views that a company's competitive advantage can be achieved when it has good management of its resources. In carrying out business activities, every company must consider risk management because the risk is an effect of uncertainty on goals that the company cannot avoid. Risk management is defined as a coordinated activity to direct and control a company related to risk (ISO 31000, 2018). This risk management needs to be carried out by resources that have sufficient capabilities to create and protect firm value.

Managers are the company's internal resources as the main actors who directly carry out activities or company operational activities. This indicates that a manager is directly involved in the company's risk management activities. In line with the RBV theory, a manager must have a managerial ability to indicate that the company's risk management can be appropriately managed. A capable manager is a manager who has extensive knowledge of the company's business management to make better judgments and estimates (Demerjian et al., 2013). Through his managerial ability in making decisions or policies related to risk management, a capable manager will significantly increase the company's value.

Increasing the firm value in the implementation of risk management through managerial ability is emphasized by stakeholder theory. Stakeholder theory (Freeman, 1984) states that the company is not an entity that only operates for its own sake but must benefit stakeholders. Creating high prosperity for stakeholders means being 
involved in the firm's value creation system. The creation and protection of firm value is the primary goal of risk management (ISO 31000, 2018). The implementation of sound risk management can be achieved if it is carried out by parties who have the capability. A manager who can risk management can use his insight, knowledge, and expertise to create prosperity and trust from stakeholders to increase the firm value.

Figure 1.

Theoretical Framework Model

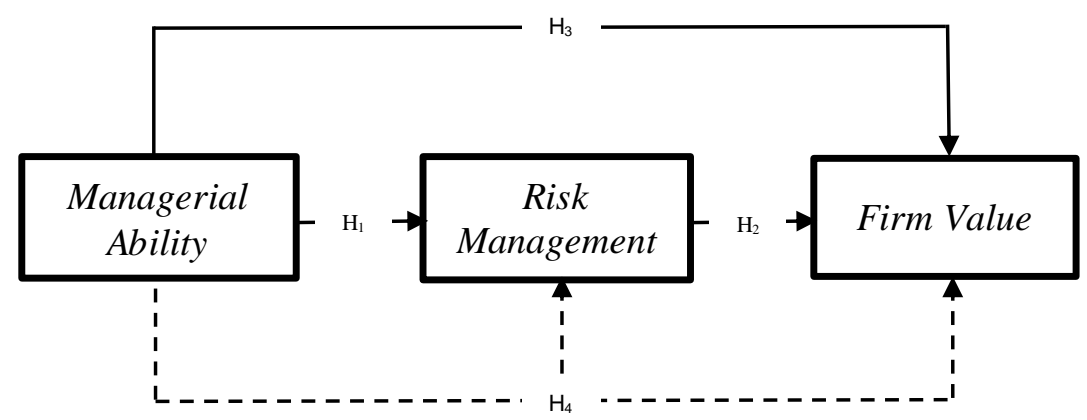

\subsection{Hypothesis Development}

\subsubsection{Managerial Ability on Risk Management}

ISO 31000 (2018) explains that risk management is a coordinated activity to direct and control risk-related organizations to achieve company goals. In implementing good risk management, the company's attention is focused not only on the risks that will arise but also on controlling risks. How to overcome risks are the main things to consider. Company management in making decisions related to company risk has different characters. The type of character of company managers is divided into two, namely, risk-averse (avoiding risk) or risk-taking (dare to take risks). The difference between the two types of managers is reflected in the company's management risk (Yung and Chen, 2018).

Barney (1991), in the theory of resource-based view, states that the company's competitive advantage can be achieved when the company has good management with the capabilities of its resources. The company's risk management is carried out directly by a manager. Managers as company resources who carry out risk management are expected to have the ability. Managerial ability indicates a management characteristic 
in the form of talent, quality, ability, and management reputation that can influence every management action and company decision-making (Wati et al., 2020). The ability possessed by a manager becomes a resource in the form of intangible assets owned by the company to carry out risk management effectively. The research of Andreou et al. (2016), Yung and Chen (2018), and Wati et al. (2020) states that managerial ability is essential because capable managers are more likely to be able to carry out risk management optimally.

Based on the conceptual arguments discussed above and the previous findings, the researcher assumes that the more capable a manager is, the more likely they are to implement risk management well. Thus, the following hypothesis can be formulated:

\section{H1: Managerial ability significantly affects risk management}

\subsubsection{Risk Management on Firm Value}

The utilization of risk management to manage all risks to the company is believed to reduce the total risk of failure of an organization and increase the efficiency and value of the company through the trust of stakeholders. Resource-based view theory (Wernerfelt, 1984) states that a company can achieve superior performance through continuous strategic assets. Effective risk management can be seen as a strategic asset for the company, where the risk management mechanism is not a trading business that can be sold or bought. In other words, each company has its specialty in risk management by its vision, mission, goals, and activities (Saeidi et al., 2020).

This is in line with the statement of Hoyt and Liebenberg (2011) that the request of another institution cannot fulfill the risk management process in one company. This means that risk management is unique for each company, and then the use of appropriate risk management can create many benefits for the company. The result of the existence of risk management as a strategic asset in the company can create a competitive advantage and improve the company's overall performance, which has an impact on increasing the firm value.

Freeman (1984), in stakeholder theory, states that stakeholders are groups or individuals who can influence and or be influenced by the activities carried out by the 
company to achieve the company's goals. Furthermore, the support obtained from stakeholders for the company influences the existence of the company itself. Implementation of risk management can increase the confidence of stakeholders that the company has been able to control risks well. This will encourage an increase in the firm value.

The research of Siregar and Safitri's (2019); Fadilah and Afriyenti (2020); Emar and Ayem (2020); Lestari et al. (2020); Fadhilah and Sukmaningrum (2020) found that the application of risk management had no significant effect on firm value. Risk management is only applied to high-risk companies (not all companies carry out risk management) and only complies with applicable regulations. Different results were found by Pamungkas (2019); Supriyadi and Setyorini (2020); Saeidi et al. (2020); Dinoyu and Septiani (2020); Yulinda et al. (2020); and Sedani and Ayu (2021) show that the company's risk management policies have a positive influence on firm value. Companies that can carry out good risk management are more attractive to investors because of the guarantee that the company has a good strategy to maximize profits.

Based on the description above and previous findings, the researcher assumes that the better the company's risk management, the less likely the company will experience failure. Thus the company can increase its company value. Thus, the hypothesis can be formulated as follows:

H2: Risk management significantly affects firm value

\subsubsection{Managerial Ability on Firm Value}

Stakeholders give trust to managers to assist them in planning, organizing, implementing, and controlling the company's operational activities (La'bi et al., 2018). In managing company activities, a manager is required to have the managerial ability. Managerial ability in the form of knowledge, insight, and expertise that managers have more about the company will encourage managers to form effective strategies and decisions in achieving company goals, namely increasing firm value. 
$\mathrm{Ng}$ and Daromes (2016) stated that higher-proficiency managers will make more accurate predictions than managers with lower abilities. The managerial ability that is used properly will produce managers who can organize, coordinate and mobilize all. resources effectively and efficiently to create and increase firm value to provide a positive view of stakeholders regarding good company performance.

Research from Ng and Daromes (2016); La'bi et al. (2018); Chuah and Foong (2019); Gong et al. (2019); Bhutta et al. (2021) found that overall managerial ability plays a vital role in improving firm performance. The experience and insight possessed by a manager in managing the company will increase the value of the company. However, Afia and Arifah (2020) and Dewiruna et al. (2020) found that the level of managerial ability did not determine the company's performance.

The company's goal in creating and increasing firm value is focused on gaining the trust of stakeholders. This is in line with stakeholder theory which states that companies provide added value to stakeholders (Freeman, 1984). Based on stakeholder theory, managers have a responsibility to maintain the company's sustainability so that a capable manager will try to increase the firm value to meet the needs of stakeholders. This means that the higher the ability possessed by a manager in managing company resources in the form of capital and labor, the higher the firm value that will be generated.

Managers who have high ability tend to use their ability in managing company activities and resources for the welfare of the interests of their stakeholders. Managers with high ability are believed to be able to make more accurate decisions than managers with low ability, so this will impact increasing the firm value.

Based on the explanation above, it can be formulated in the following hypothesis: H3: Managerial ability significantly affects firm value

\subsubsection{Mediation Role of Risk Management on the Effect of Managerial Ability on} Firm Value

Capable managers have better communication skills, insight, and knowledge that help build the trust of market participants by effectively portraying the positive aspects 
of the firm's future stable earnings at a minimum level of manageable risk (Yung and Chen, 2018). Risk management in the company is managed directly by a manager as the manager of the company's operational activities (Wati et al., 2020). Therefore, the managerial ability is needed in implementing risk management properly. Good risk management interprets risk management and good company internal control. This will be responded to positively by market participants by providing a high investment price to increase the company's value.

RBV theory (Barney, 1991) states that companies with competent human resources will affect the increase in competitive advantage seen from employee productivity, which shows employees' expertise in managing the company. Managerial ability possessed by a manager is an intangible asset resource that can be used to increase the success of the company's risk management, which will have an impact on increasing the prosperity of stakeholders.

In line with stakeholder theory by Freeman (1984), which explains that stakeholder theory focuses on helping company managers understand their stakeholder environment and manage more effectively in their corporate environment. Managers are obliged to run the company's operations and meet the company's needs and can provide added value to investors and meet the needs of other company stakeholders. Therefore, managers will use their ability to increase the firm value through risk management to benefit stakeholders.

The research of Yung \& Chen (2018); and Wati et al. (2020) found that capable managers are more likely to carry out risk management optimally. Research conducted by Pamungkas (2019); Supriyadi \& Setyorini (2020); Dinoyu \& Septiani (2020); Yulinda et al. (2020); and Sedani \& Ayu (2021) show that the company's risk management policies have a positive influence on a firm value. Companies that can carry out good risk management are more attractive to investors because of the guarantee that the company has an excellent strategy to maximize profits. This result is shown by Hoyt \& Liebenberg (2011) through their empirical results, which find that applying risk management will increase firm value by $3.6 \%-17 \%$. 
Based on the conceptual arguments discussed above, the following hypothesis is formulated:

H4: Risk management mediates the effect of managerial ability on firm value

\section{Research Method}

\subsection{Research Design}

This research is explanatory research that builds a causal relationship, which tests a theory or hypothesis from pre-existing research. The population in this study were all companies listed on the Indonesia Stock Exchange (IDX) from 2018 to 2020. The procedure for determining the sample in this study was non-probability or non-random selection using the purposive sampling technique. The criteria for selecting the sample in this study, namely 1). non-financial companies that are continuously listed on the IDX during the period 2018-2020 and have a closing date of December 31; 2). During 2018-2020, the company publishes a complete annual report in rupiah currency; 3 ). The company provides all the necessary information regarding the variables to be studied.

The type of data in this study uses documentary data by collecting and analyzing documents in financial reports and annual reports. The source of data used in this study is secondary data. The secondary data in this study are financial reports and annual reports that have been published from the Indonesia Stock Exchange (IDX) database for the 2018-2020 period obtained through the official website www.IDX.co.id.

\subsection{Operational Definition and Measured Variable}

\subsubsection{Managerial Ability}

Managerial ability is a manager's expertise in making and implementing decisions that can lead the company to a high-efficiency level. Efficiency is the minimum use of resources to achieve optimum results (Demerijan et al., 2013).

The managerial ability variable in this study acts as an independent variable, which is measured using the DEA (Data Envelopment Analysis) measurement reference developed by Demerjian et al. (2012). DEA calculates efficiency using weighted outputs against weighted inputs. The measurement of managerial ability variables is as follows: 


\section{Firm Efficiency}

$$
\begin{aligned}
& =\alpha_{0}+\beta_{1} \ln (\text { Total Assets })+\beta_{2} \text { Market Share }_{i} \\
& +\beta_{3} \text { Free Cash Flow Indicator }_{i}+\beta_{4} \text { In }(\text { Age })_{i} \\
& +\beta_{5} \text { Business Segment Concentration }_{i} \\
& +\beta_{6} \text { Foreign Currency Indicator }_{i}+\varepsilon i
\end{aligned}
$$

Information :

Total Asset $=$ The total value of the company's assets at the end of the year.

Market Share $=$ Net profit margin, which is the percentage of profit to sales.

Free Cash Flow Indicator $=$ Score 1 if the company does not have a negative free cash flow and 0 if the company has a negative free cash flow.

Firm Age $=$ The length of time the company is listed on the Indonesia Stock Exchange. Business Segment Concentration $=$ Comparison between largest segment sales and total sales.

Foreign Currency Indicator $=$ Score 1 if the company has no foreign currency adjustments at the end of the year and 0 if the company has foreign currency adjustments at the end of the year by translating foreign currencies.

The greater the estimated value obtained from Firm Efficiency, the better the company's efficiency achievement will be. Observation values greater than 1 indicate that the company uses inputs efficiently, and values less than 1 indicate that it needs to reduce costs or increase its income to achieve efficiency (Demerjian et al., 2013). While firm efficiency, according to Demerjian et al. (2012), will be calculated by the following formula:

$$
\operatorname{Max}_{\boldsymbol{v}} \boldsymbol{\theta}=\frac{\text { Sales }}{v_{1} \text { COGS }+v_{2} \text { SGandA }+v_{3} P P E+v_{4} \text { OpsLease }+v_{5} \text { RandD }+v_{6} \text { Goodwill }+v_{7} \text { OtherIntan }}
$$

Information :

Sales $\quad=$ Total sales

COGS = Total cost of goods sold 
SGandA = Total selling and administrative expenses

$P P E \quad=$ Net value of property, plant dan equipment

OpsLease = Net operating leasing

RandD $\quad=$ Total research and development costs

Goodwill= Total goodwill

OtherIntan = Amount of other intangible assets

The greater the value of $\operatorname{Max}_{v} \theta$ indicates that the better the manager's ability to manage inputs to produce an output. The use of these seven inputs considers that every company's operational activities are strategies and policies taken by a manager. Every policy taken by managers is expected to influence sales. To achieve maximum value from sales, a manager must control and use resources optimally within the company (Ng and Daromes, 2016).

\subsubsection{Risk Management}

Risk management is a coordinated activity to direct and control companies related to risk to create and protect company value (ISO 31000, 2018). Risk itself is the effect of uncertainty on goals. These effects can be positive, negative, or both and can overcome, create or generate opportunities and threats.

The risk management variable in this study acts as an intervening variable, which is measured using the International Standard Organization (ISO) 31000 Framework index, which consists of 25 criteria items covering five dimensions, namely mandate and commitment, framework planning, risk management implementation, monitoring and continuous improvement according to the ISO 31000 component standard, which can be seen in the appendix. Each risk management item the company applies is given a score of 1 and 0 if it is not applied. Then each item will be summed, and a risk manage ment index is made, which is obtained from the calculation:

$$
\boldsymbol{R M} \mathbf{I n d e x}=\frac{\sum \text { risk management implementation items }}{25 \text { items of risk management implementation }}
$$




\subsubsection{Firm Value}

The firm value is a description of the public's trust in the company after going through activities for several years since the company was founded until now ( $\mathrm{Ng}$ and Daromes, 2016). Furthermore, the firm value is an investor's perception of the company, which is often associated with increasing or decreasing stock prices. High stock prices make the value of the company high, and the higher the firm value indicates the high prosperity of the stakeholders.

The firm value variable in this study acts as the dependent variable, which is measured using Tobin's Q measurement following the research of Gaio and Raposo (2011), which can be calculated using the following formula:

$$
\boldsymbol{Q}_{i, t}=\frac{\left(B V A_{i, t}+M V E_{i, t}-B V E_{i, t}\right)}{B V A_{i, t}}
$$

Information :

$Q_{i t} \quad=$ Firm Value

$B V A_{i t}=$ Book Value of Total Asset

$M V E_{i t}=$ Market Value of Common Equity (closing price $\times$ number of shares outstanding)

$B V E_{i t}=$ Book Value of Equity

\subsection{Research Analysis Method}

This study uses descriptive analysis to describe the research variables. The descriptive statistics used are the average, minimum, maximum, and standard deviation. The data analysis method in this study was carried out through several stages, namely data normality test, classical assumption test (multicollinearity test; autocorrelation test; heteroscedasticity test), simultaneous test, coefficient of determination test, and $\mathrm{t}$ statistical test (Ghozali, 2012) and Sobel mediation test (Sobel, 1982) to examine the role of intervening variables. This research was conducted using a path analysis model. The path analysis equation in this study is formulated into two sub-structures as follows: 


$$
\begin{aligned}
& Y_{1}=a+\beta y_{1} x+\beta y_{1} \varepsilon_{1} \ldots \ldots \\
& Y_{2}=a+\beta y_{2} y_{1}+\beta y_{2} x+\beta y_{2} \varepsilon_{2}
\end{aligned}
$$

Information :

$$
\begin{aligned}
& \mathrm{a}=\text { Constant } \\
& \beta \quad=\text { Regression Coefficient } \\
& x=\text { Managerial Ability } \\
& y_{1} \quad=\text { Risk Management } \\
& y_{2} \quad=\text { Firm Value } \\
& \varepsilon_{1} \text { and } \varepsilon_{2}=\text { Unexplained Variance }
\end{aligned}
$$

\section{Results and Discussion}

Based on the predetermined sample criteria, the number of companies that meet the criteria for each period is 284 from 738 companies listed on the Indonesia Stock Exchange (IDX). The total number of analysis units during the 2018 to 2020 observation period is 852 units of analysis.

Table 1.

Research Sample Summary

\begin{tabular}{lc}
\hline \multicolumn{1}{c}{ Criteria } & Sample (N) \\
\hline Population & 738 \\
Financial company & $(105)$ \\
Non-financial companies that are not continuously listed on the & \\
Indonesia Stock Exchange during the 2018-2020 period & \\
$\begin{array}{l}\text { Non-financial companies with incomplete annual report data and } \\
\text { financial data in foreign Currency }\end{array}$ & $(183)$ \\
\hline Total Sample (N) & 284 \\
\hline
\end{tabular}

The number of companies sampled for each year is 284 companies so that the number of units of analysis becomes 852 units for three periods. However, some data outliers were excluded from this study. The researcher then detects outlier data by converting the data into a standardized score (Z-score). Data will be excluded from the sample if data has a Z-score value greater than 1.96 or less than -1.96 . Thus, the total 
unit of final analysis is 549 units of analysis after 303 outliers are excluded from the sample.

\subsection{Descriptive Statistics}

The descriptive statistical calculations result of managerial ability, risk management, and firm value are shown in table 2:

Table 2.

Descriptive Statistical Results

\begin{tabular}{lccccc}
\hline \multicolumn{1}{c}{ Variable } & $\mathrm{N}$ & Minimum & Maximum & Mean & Std. Deviation \\
\hline Managerial Ability & 549 & 1.408 & 1.571 & 1.487 & 0.037 \\
Risk Management & 549 & 0.440 & 0.880 & 0.665 & 0.126 \\
Firm Value & 549 & 0.048 & 2.887 & 1.271 & 0.603 \\
Valid N (listwise) & 549 & & & & \\
\hline \multicolumn{2}{l}{ Source: SPSS Processed Data (2021) } & & &
\end{tabular}

Based on the descriptive statistics in table 1 above, managerial ability in the sample companies showed the lowest value of 1,408 and the highest value of 1,571, with an average managerial ability of 1,487 and a standard deviation of 0.037 . This shows that, on average, the sample companies have the good managerial ability, meaning that most sample companies can manage their company resources well. The descriptive statistics for the risk management variable show a minimum value of 0.440 and a maximum value of 0.880 with an average value of 0.665 and a standard deviation of 0.126 . This shows that, on average, the sample companies have implemented risk management because they have an average beta of 0.665 or $66.50 \%$ of the ISO 31000 framework index.

The results of descriptive statistics on the lowest and highest firm values are 0.048 and 2.887, respectively, with an average value of 1.271 and a standard deviation of 0.603. This shows that the average company value in Indonesia is quite good because it has a value of more than 1 . It has promising long-term prospects for the prosperity of the company's stakeholders. All variables in this study have a standard deviation value that is smaller than the average value, which indicates that there is not much data that 
deviates from the average value. The nature of the data from this study tends to be spread out.

\subsection{Regression Model Results in Path Analysis}

After the model suitability test (Goodness-of-Fit Model) was fulfilled, the researcher tested the hypothesis using the regression model in path analysis to predict the relationship between exogenous and endogenous variables. The following are the standardized value path coefficients presented in Table 3 and Table 4.

Table 3.

Standardized Value Path Coefficient Result - Sub-structure 1

\begin{tabular}{|c|c|c|c|c|}
\hline Variable & & $\begin{array}{c}\text { Regression } \\
\text { Coeficient } \\
(\boldsymbol{\beta}) \\
\end{array}$ & Sig. & Information \\
\hline $\begin{array}{l}\text { Managerial Ability } \\
\text { Management }\end{array}$ & & 0.428 & 0.000 & Significant \\
\hline Constant & -1.475 & & & \\
\hline$\varepsilon_{1}$ & 0.904 & & & \\
\hline Kolmogorov-Smirnov Z & 0.108 & & & \\
\hline Autocorrelation Test & 1.748 & & & Durbin-Watson \\
\hline Heteroscedasticity Test & 0.110 & & & MA on $R M$ \\
\hline Simultaneous Test & 0.000 & & & Sig. F \\
\hline Coefficient of Determination Test & 0.182 & & & Adjusted $R$ square \\
\hline \multicolumn{5}{|l|}{ Source: SPSS Processed Data (2021) } \\
\hline \multicolumn{5}{|c|}{$\begin{array}{l}\text { Table } 4 . \\
\text { Standardized Value Path Coefficient Result - Sub-structure } 2\end{array}$} \\
\hline Variable & & $\begin{array}{l}\text { Regression } \\
\text { Coeficient } \\
(\boldsymbol{\beta})\end{array}$ & Sig. & Information \\
\hline Risk Management on Firm Value & & 0.238 & 0.000 & Significant \\
\hline Managerial Ability on Firm Value & & 0.374 & 0.000 & Significant \\
\hline Constant & -8.067 & & & \\
\hline$\varepsilon_{1}$ & 0.827 & & & \\
\hline Kolmogorov-Smirnov Z & 0.492 & & & \\
\hline Multicollinearity Test & $\begin{array}{r}0.813 \\
1.230 \\
0.804 \\
1.243\end{array}$ & & & $\begin{array}{c}\text { Tolerance; VIF- } \\
\text { RM on FV } \\
\text { Tolerance; VIF- } \\
\text { MA on FV }\end{array}$ \\
\hline Autocorrelation Test & 1.431 & & & Durbin-Watson \\
\hline Heteroscedasticity Test & 0.334 & & & $R M$ on $F V$ \\
\hline & 0.112 & & & MA on $F V$ \\
\hline Simultaneous Test & 0.000 & & & Sig. F \\
\hline Coefficient of Determination Test & 0.315 & & & Adjusted $R$ square \\
\hline
\end{tabular}


The path diagram model of Tables 3 and 4 is depicted in Figure 2.

Figure 2.

Path Diagram Model

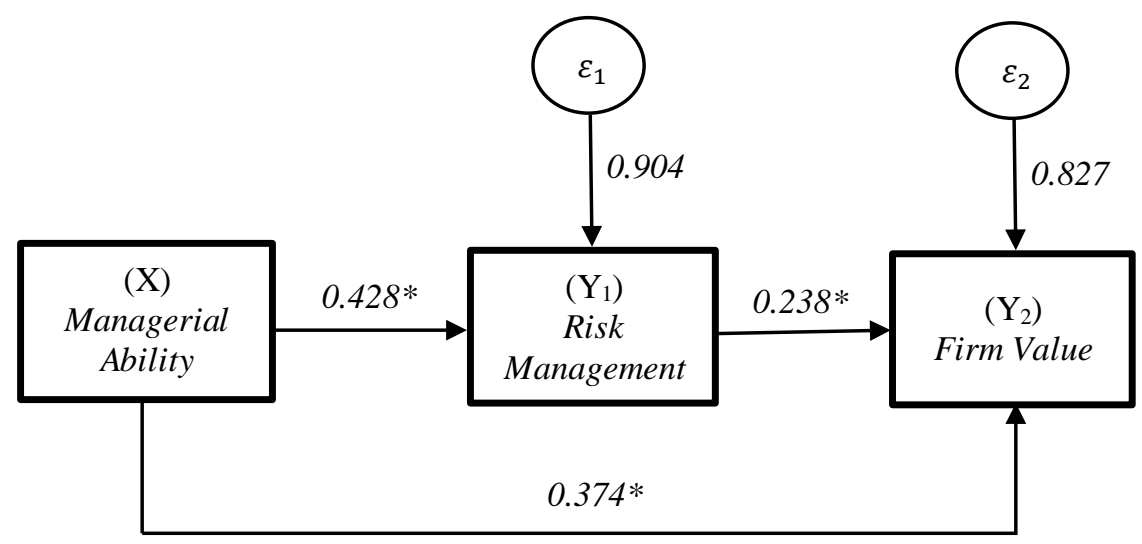

*Sig. $<0.05$

\subsection{Sobel Test}

This study uses the Sobel test (Sobel, 1982) to examine the indirect effect or mediating role of risk management on the relationship between managerial ability and firm value. The results of the Sobel test calculations are presented in Table 5.

Table 5.

Sobel Test Calculation Results

\begin{tabular}{|c|c|c|c|}
\hline Variable Combination & $\begin{array}{l}\text { Estimated } \\
\text { Value }\end{array}$ & Standard Error & p-value of Sobel Test \\
\hline $\begin{array}{l}\text { The effect of managerial ability } \\
\text { on firm value through risk } \\
\text { management }\end{array}$ & $1.441 ; 1.139$ & $0.131 ; 0.188$ & 0.000 \\
\hline $\begin{array}{l}\text { Source: SPSS Processed Data (2021) } \\
\text { Calculations with the help of the }\end{array}$ & & & 4.0 \\
\hline
\end{tabular}

The results of the Sobel test analysis in table 5 above indicate that the indirect effect of managerial ability on firm value has a p-value of Sobel of $0.000<0.05$. Thus, the risk management variable in this study is a Full Mediation type, so it can be concluded that the risk management variable plays a role in mediating the relationship between managerial ability and firm value. 


\subsection{Hypothesis Test}

The results of the hypothesis test are presented in Table 6

Table 6.

Hypothesis Test Results

Hypothesis

Hypothesis Test

Results

\begin{tabular}{ll}
\hline $\mathrm{H}_{1}:$ Managerial ability significantly affects risk management & Accepted \\
$\mathrm{H}_{2}:$ Risk management significantly affects firm value & Accepted \\
$\mathrm{H}_{3}:$ Managerial ability significantly affects firm value & Accepted \\
$\mathrm{H}_{4}:$ Risk management mediates the effect of managerial ability on firm & Accepted \\
value & \\
\hline
\end{tabular}

Source: SPSS Processed Data (2021)

The managerial ability has an effect of 0.428 with a significance probability value of 0.000 , smaller $(<)$ than 0.05 . Thus, it can be concluded that managerial ability has a positive and significant influence on risk management. Thus, $\mathrm{H}_{1}$, which states that managerial ability $(\mathrm{X})$ has significantly affected risk management $\left(\mathrm{Y}_{1}\right)$, is accepted.

Risk management influences 0.238 with a significance probability value of 0.000 , smaller $(<)$ than 0.05 . Thus, it can be concluded that risk management has a positive and significant effect on firm value. Thus, $\mathrm{H}_{2}$, which states that risk management $\left(\mathrm{Y}_{1}\right)$ has a significant effect on firm value $\left(\mathrm{Y}_{2}\right)$, is accepted.

The managerial ability has an effect of 0.374 with a significance probability value of 0.000 , smaller $(<)$ than 0.05 . Thus, it can be concluded that managerial ability has a positive and significant effect on firm value. Thus, $\mathrm{H}_{3}$, which states that managerial ability $(\mathrm{X})$ significantly affects firm value $\left(\mathrm{Y}_{2}\right)$, is accepted.

Managerial ability $(\mathrm{X})$ on firm value $\left(\mathrm{Y}_{2}\right)$ through risk management $\left(\mathrm{Y}_{1}\right)$ has a significant probability value of 0.000 which is smaller $(<)$ than 0.05 . Thus, it can be concluded that risk management mediates the effect of managerial ability on firm value. Thus, $\mathrm{H}_{4}$, which states that risk management mediates the effect of managerial ability on firm value, is accepted. 


\subsection{Discussion}

Based on the results of path analysis using the SPSS 20.0 program (Ghozali, 2012), the research results are explained as follows:

\section{Effect of Managerial Ability on Risk Management}

The results of hypothesis testing indicate that managerial ability statistically affects risk management, so hypothesis 1 is accepted. These results indicate that companies that have managers with high managerial ability will be able to manage risk more optimally through the implementation of risk management because managers with high ability have better insight, knowledge, and experience regarding the company's environmental conditions so that they know better how to manage the risks that exist in the company.

Managers with high ability have a superior understanding of managing company activities that will support managers to make the right decisions to reduce and minimize the risks that exist in the company so that the implementation of risk management becomes more effective. The managerial ability makes managers better able to consider the costs and benefits of existing risk management to become more effective, such as using CCTV compared to using supervisors in controlling fraud risk by company employees related to human resource risk.

The theory of resource-based view (Barney, 1991) states that its competitive advantage can be achieved when the company has good management with its resource capabilities. Concerning the RBV theory, managers as company resources must maximize their ability in risk management. Managerial ability indicates a management characteristic in the form of talent, quality, ability, and reputation of management that can affect every risk management activity in the company. The ability possessed by a manager becomes a resource in the form of intangible assets owned by the company to carry out risk management properly.

The results of this study are consistent with the research of Andreou et al. (2016); Yung and Chen (2018); Wati et al. (2020), who found the results that managerial ability is essential for a manager because capable managers are more likely to be able to carry out risk management effectively. 


\section{Effect of Risk Management on Firm Value}

The results of hypothesis testing indicate that risk management statistically affects firm value, so hypothesis 2 is accepted. These results indicate that better risk management practices through the application of risk management carried out by a company will be able to assure stakeholders that the risks to the company can be controlled and appropriately managed to increase the trust and prosperity of the stakeholders, which is reflected through the increase in firm value.

Every activity carried out by the company has risks. The high risk can hamper the company's performance. When risk increases, the company's performance will be disrupted due to factors inside and outside the company that cannot be controlled, such as liquidity, financial, operational, market, and compliance risks. When the company's performance is disrupted, this will impact the decline in stock prices that reflect the firm value so that it can harm the company and investors. Therefore, companies need to protect company activities by implementing risk management so that risks can be controlled and minimized. Companies that implement risk management show that the company can control risk, which means that the company has much information to prevent the risks faced so that the firm value can be protected and increased.

Resource-based view theory (Wernerfelt, 1984) states that a company can achieve superior performance or competitive advantage through the continuous use of strategic assets. Effective risk management can be seen as a strategic asset for the company. The risk management mechanism is not a trading business that can be bought or sold. In other words, each company has its specialty in risk management by its vision, mission, goals, and activities. The result of the existence of risk management as a strategic asset in the company can create a competitive advantage and improve the company's overall performance, which has an impact on increasing the firm value.

Freeman (1984), in stakeholder theory, states that companies must provide benefits not only to the company but also to its stakeholders. Companies that implement risk management will provide benefits in the form of protecting company assets from risks such as exchange rate fluctuations so that investors do not experience losses and will 
trust the company; this will lead to an increase in stock prices and company assets and also have an impact on increasing firm value.

The results of this study are consistent and in line with the research of Pamungkas (2019); Supriyadi and Setyorini (2020); Saeidi et al. (2020); Dinoyu and Septiani (2020); Yulinda et al. (2020); Sedani and Ayu (2021) who found that the more effective the risk management carried out by the company, the less likely the company will fail; thus the company can increase its firm value.

\section{Effect of Managerial Ability on Firm Value}

The results of hypothesis testing indicate that managerial ability statistically affects firm value, so hypothesis 3 is accepted. The results of this study indicate that the higher the managerial ability possessed by managers in managing the company's resources, the more efficient the company is, which will have an impact on increasing the firm value. Managers as agents in the company are expected to have the ability to be able to manage the company optimally so that, in the end, it will make a maximum contribution to the performance and value of the company.

Managers with higher ability will make more accurate predictions than managers with lower ability. High managerial ability means that managers can organize, coordinate, and mobilize all resources effectively and efficiently to achieve the organization's goals. Managers with knowledge, experience, and skills are expected to make the right decisions to increase investor confidence and increase firm value.

Donaldson and Preston (1995) suggest that stakeholders are concerned with managerial management in recommending attitudes, structures, and practices that are carried out simultaneously to form stakeholder management. In this relationship, there is a contract where stakeholders delegate authority to managers to manage the company optimally and make the best decisions for stakeholders. In line with stakeholder theory, managers as agents appointed by stakeholders will use their skills to improve company performance, such as using company assets efficiently to create a broad market share for the company by paying attention to the company's best revenue segment and being 
able to consider changes in value foreign currency exchange to provide benefits for stakeholders in increasing the firm value.

The results of this study are consistent with research conducted by $\mathrm{Ng}$ and Daromes (2016); La'bi et al. (2018); Chuah and Foong (2019); Gong et al. (2019); Bhutta et al. (2021), which states that managerial ability has a positive influence on firm value. This indicates that managers who have efficient company management skills can make more precise decision-making processes. Thus, investor confidence will tend to increase, and the firm value will be better.

\section{Mediation Role of Risk Management on the Effect of Managerial Ability on Firm Value}

The results of hypothesis testing indicate that risk management statistically mediates the effect of managerial ability on firm value, so hypothesis 4 is accepted. This study indicates that the company's risk management through effective risk management by a manager who has high managerial ability will increase the firm value. Managers with high ability will consider continuously improving the quality of performance and maintaining stakeholder participation by maximizing the benefits obtained for the company's progress. Therefore, managers tend to try to provide added value to the company with proper risk management through risk management. By using the right method, managers who have the managerial ability will be able to minimize the costs incurred to minimize risk and then increase the benefits to increase and protect the firm value.

The resource-based view theory proposed by Barney (1991) states that companies have competent human resources, thus affecting the increase in competitive advantage as seen from employee productivity, which shows employees' expertise in managing the company. Managerial ability possessed by a manager is an intangible asset resource that can be used to increase the success of the company's risk management, which will have an impact on increasing the prosperity of stakeholders.

This is consistent with the stakeholder theory by Freeman (1984), which explains that managers are obliged to run the company's operations and meet the company's 
needs and can provide additional value for investors and meet the needs of other stakeholders. In line with stakeholder theory, stakeholders will select and assign managers who have high managerial ability to determine appropriate strategies and actions so that company operations continue and firm value can be achieved.

A manager will carry out his duties by the wishes of his stakeholders, namely to maintain the company's sustainability. The existence of the company's sustainability which is reflected in risk management through the implementation of risk management, will increase the market value of the company's equity in the future. This is because investors believe that the company can control the existing risks and provide benefits for themselves.

\section{Conclusion, Implication, and Limitation}

\subsection{Conclusion}

The managerial ability has a positive and significant impact on risk management. Managers who have the high ability can manage, regulate, coordinate, and mobilize all company resources efficiently and effectively in the application of risk management to optimize risk management. Risk management has a positive and significant impact on firm value. The company's concern for implementing risk management will help prevent risks that may occur in the future. Controlled risk will make the company's performance better and will be reflected in the firm value. In addition, the implementation of risk management by the company will assure that the risk has been appropriately managed and can be controlled by the company to increase the trust of stakeholders, which is marked by an increase in the firm value.

The managerial ability has a positive and significant impact on firm value. High managerial ability indicates that managers can manage, organize, coordinate, and mobilize all existing resources in the company efficiently in the company's operating activities to achieve company goals so that it can increase the prosperity of the stakeholders and the firm value will increase. The role of the risk management variable significantly mediates the relationship between managerial ability and firm value. Investors in investing do not only consider current earnings results to make investment 
decisions, further investors consider the risk of the investment made. Investors as company stakeholders look more at the ability possessed by a manager in managing the risks contained in the company, including investment risk, liquidity risk, market risk, and others through the application of risk management to assure that risk has been managed to a minimum level of risk to generate profits in the future to attract other investors to invest which will have an impact on increasing the firm value.

\subsection{Research Implication}

Theoretically, the results of this study are generally consistent with the theory that the researcher has built. This research can have implications in scientific development and research. It can be used as a reference for further research on the effect of managerial ability on firm value, with risk management as an intervening variable. This research can also be used as academic learning material that several factors influence the increase in firm value through applying risk management by managerial ability.

This research can provide practical implications as a lesson for corporate management in organizational life. Company management is motivated to improve their managerial ability in managing risks that exist in the company effectively and efficiently through the application of risk management that is useful for the company's sustainability.

For investors, the practical implications of this research are expected to provide benefits in the form of an overview in investing in assessing a company which is not only through the conditions of its income and profits but also considers the policies and activities carried out by the company through the company's risk management so that uncertainty about the future can be minimized for the welfare of investors.

For regulators, the practical implications of this research are expected to be reference material or input to continue to improve regulations related to the implementation of risk management to assure stakeholders against corporate uncertainty that will occur in the future. 


\subsection{Limitation and Recommendation}

This study has several limitations which can be used as directions for further research. First, the research sample period used in this study is relatively short, only three years from the 2018-2020 period, so it cannot show the level of tendency in the long term. Second, the data that the researcher has tabulated has extreme values, so that it is required to remove outlier data to get data that is normally distributed. Third, this study uses secondary data with quantitative research methods, so it is likely to produce different analytical results from research using qualitative or mixed methods. Fourth, this study does not use control variables to explain, more specifically, the independent variables in this study.

Based on the limitations of this study, several recommendations can be taken into consideration by further researchers to obtain better results. First, extend the observation period of the sample so that the research period is longer. Thus, the research results are expected to be more accurate. Second, further research can use all companies listed on the Indonesia Stock Exchange as research samples or by comparing the application of risk management in each industrial sector so that research related to risk management on firm value is more accurate.

Third, further researchers may consider using qualitative or mixed research methods to observe the implementation of risk management in the company directly so that the research results can describe the company's actual state. Fourth, further research can consider using other variables outside of the variables used in this study, such as factors from the risk management committee and firm size as expected to influence the level of application of corporate risk management on firm value.

\section{Reference}

Afia, I. N., and Arifah, D. A. (2020). Pengaruh Kemampuan Manajerial dan Komite Audit terhadap Nilai Perusahaan melalui Kualitas Laba. Prosiding Konferensi Ilmiah Mahasiswa Unissula (KIMU) Klaster Ekonomi, 3, 138-155. Retrieved from: http://jurnal.unissula.ac.id/index.php/kimue/article/view/9747. 
Andreou, P. C., Philip, D., and Robejsek, P. (2016). Bank Liquidity Creation and Risk-Taking: Does Managerial Ability Matter?. Journal of Business Finance \& Accounting, 43(12), 226-259. doi: 10.1111/jbfa.12169.

Barney, J. (1991). Firm Resources and Sustained Competitive Advantage. Journal of Management, 17(1), 99-120. doi: 10.1177\%2F014920639101700108.

Bhutta, I. A., Sheikh, M. F., Munir, A., Naz, A., and Saif, I. (2021). Managerial Ability and Firm Performance: Evidence from an Emerging Market. Cogent Business \& Management, 8(1), 1-22. doi: 10.1080/23311975.2021.1879449.

Chuah, S. F., and Foong, S. S. (2019). Managerial Ability and Firm Performance in Malaysia: Do Families and Foreignness of the CEOs Matter?. Review of Pacific Basin Financial Markets and Policies, 22(3). doi: 10.1142/S0219091519500176.

Demerjian, P. R., Lev, B., Lewis, M. F., and McVay, S. E. (2013). Managerial Ability and Earnings Quality. The Accounting Review, 88(2), 463-498. doi: 10.2308/accr-50318.

Demerjian, P. R., Lev, B., and McVay, S. E. (2012). Quantifying Managerial Ability: A New Measure and Validity Tests. Managerial Science, 58(7), 1229-1248. doi: 10.1287/mnsc. 1110.1487 .

Dewiruna, I., Subroto, B., and Subekti, I. (2020). The Effect of R\&D Intensity, Intellectual Capital, and Managerial Ability on Firm's Performance with Political Connection as a Moderating Variable. The Indonesian Accounting Review, 10(1), 13-24. doi: 10.14414/tiar.v10i1.1909.

Dinoyu, M. F., and Septiani, A. (2020). Analisis Pengaruh Implementasi Enterprise Risk Management terhadap Kinerja dan Nilai Perusahaan. Diponegoro Journal of Accounting, 9(4), 1-11. Retrieved from: https://ejournal3.undip.ac.id/index.php/accounting/article/view/29110.

Donaldson, T., and Preston, L. (1995). The stakeholder theory of the corporation: Concepts, evidences, implication. Academy of Management Review, 20(1), 65-91. doi: 10.5465/amr.1995.9503271992.

Emar, S, E, A., and Ayem, S. (2020). Pengaruh Pengungkapan Enterprise Risk Management dan Pengungkapan Intellectual Capital terhadap Nilai Perusahaan dengan Good Corporate Governance Sebagai Moderasi. Jurnal Ekonomi, Bisnis dan Akuntansi, 19(2), 78-90. doi: 10.22225/we.19.2.1956.79-90.

Fadhilah, M., and Sukmaningrum, P. S. (2020). The Effect of Enterprise Risk Management (ERM), Company Performance and Size on Value. Jurnal Ekonomi Syariah Teori dan Terapan, 7(5), 926-939. doi: 10.20473/vol7iss20205pp926-939. 
Fadilah, R., and Afriyenti, M. (2020). Pengaruh Intellectual Capital, Perencanaan Pajak, dan Pengungkapan Enterprise Risk Management terhadap Nilai Perusahaan. Wahana Riset Akuntansi, 8(1), 82-94. doi: 10.24036/wra.v8i1.109056.

Freeman, R. E. (1984). Strategic Management: A Stakeholder Approach. London: Pitman Publishing Inc.

Gaio, C., and Raposo. C. (2011). Earnings Quality and Firm Valuation: International Evidence. Accounting and Finance, 5(2), 467-499. doi: 10.1111/j.1467-629X.2010.00362.x.

Ghozali. (2012). Aplikasi Analisis Multivariate dengan Program IBM SPSS. Yogyakarta: Universitas Diponegoro.

Gong, Y., Yan, C., and Ho, K. C. (2021). The Effect of Managerial Ability on Corporate Social Responsibility and Firm Value in the Energy Industry. Corporate Social Responsibility and Environmental Management, 28(2), 581-594. doi: 10.1002/csr.2070.

Hoyt, R. E., and Liebenberg, A. P. (2011). The Value of Enterprise Risk Management. Journal of Risk and Insurance, 78(4), 795-822. doi: 10.1111/j.1539-6975.2011.01413.x.

International Organization for Standardization (ISO). (2018). ISO 31000: 2018 Risk Management - Guidelines, Switzerland.

La'bi, O. B., Ng, S., and Lukman, L. (2018). Peran Kemampuan Manajerial terhadap Manajemen Laba dan Biaya Modal Ekuitas Sebagai Mekanisme dalam Meningkatkan Nilai Perusahaan. AJAR, 1(1), 113-156. doi: 10.35129/ajar.v1i01.52.

Lestari, D., Santoso, B., and Hermanto, H. Pengaruh Dewan Komisaris, Komite Direksi dan Enterprise Risk Management Disclosure terhadap Nilai Perusahaan. E-Jurnal Akuntansi, 30(4), 945-957. doi: 10.24843/EJA.2020.v30.i04.p12.

Malik, I., and Simatupang, A. (2021). Nilai Perusahaan Akibat Pelaksanaan Enterprise Risk Management (ERM). Economics and Digital Business Review, 2(1), 1-13. doi: 10.37531/ecotal.v2i1.24.

Ng, S., and Daromes, F. E. (2016). Peran Kemampuan Manajerial Sebagai Mekanisme Peningkatan Kualitas Laba dan Nilai Perusahaan. Jurnal Akuntansi Dan Keuangan Indonesia, 13(2), 174-193. doi: 10.21002/jaki.2016.10.

Nurhikmah, E., and Setiany, E. (2020). The Effect of External, Internal and Managerial Risk on Firm Value. Scholars Middle East Publishers, Dubai, United Arab Emirates, 131138. doi: 10.36348/sb.2020.v06i05.003.

Pamungkas, A. (2019). Pengaruh Penerapan Enterprise Risk Management (COSO) terhadap Nilai Perusahaan: Studi Empiris pada Perusahaan Manufaktur yang Terdaftar di BEI. Jurnal Akuntansi, 11(1), 12-21. doi: 10.28932/jam.v11i1.1539. 
Saeidi, P., Saeidi, S. P., Gutierrez, L., Streimikiene, D., Alrasheedi, M., Saeidi, S. P., and Mardani, A. (2020). The Influence of Enterprise Risk Management On Firm Performance with the Moderating Effect of Intellectual Capital Dimensions. Economic Research-Ekonomska Istraživanja, 34(1), 122-151. doi: 10.1080/1331677X.2020.1776140.

Sedani, N. K. A., and Ayu, P. C. (2021). Pengaruh Pengungkapan Enterprise Risk Management, Pengungkapan Intellectual Capital dan Ukuran Dewan Komisaris terhadap Nilai Perusahaan. Hita Akuntansi dan Keuangan, 2(1), 461-474.

Siregar, N. Y., and Safitri, T. A. (2019). Pengaruh Pengungkapan Enterprise Risk Management, Intellectual Capital, Corporate Social Responsibility, dan Sustainability Report terhadap Nilai Perusahaan. Jurnal Bisnis Darmajaya, 5(2), 53-79. Retrieved from: https://jurnal.darmajaya.ac.id/index.php/JurnalBisnis/article/view/1589

Sobel, M. E. (1982). Asymptotic Confidence Intervals for Indirect Effects in Structural Equation Models. Sociological Methodology, 13, 290-321. doi: 10.2307/270723.

Soper, D. S. (2021). Sobel Test Calculator for the Significance of Mediation [Software]. Retrieved from: https://www.danielsoper.com/statcalc.

Supriyadi, A., and Setyorini, C. T. (2020). Pengaruh Pengungkapan Manajemen Risiko terhadap Nilai Perusahaan melalui Kinerja Keuangan di Industri Perbankan Indonesia. Owner: Riset dan Jurnal Akuntansi, 4(2), 467-484. doi: 10.33395/owner.v4i2.257.

Wati, E. R., Tjaraka, H., and Sudaryati, E. (2020). Do Managerial Ability Impact Indonesian Firm Risk-Taking Behavior?. AKRUAL: Jurnal Akuntansi, 12(1), 18-33. doi: 10.26740/jaj.v12n1.p18-33.

Wernerfelt, B. (1984). A Resource-Based View of the Firm. Strategic Management Journal, 5(2), 171-180. doi: 10.1002/smj.4250050207.

Yulinda, N., Nasir, A., and Savitri, E. (2020). Pengaruh Pengungkapan Manajemen Risiko Perusahaan dan Modal Intelektual terhadap Nilai Perusahaan. Bilancia: Jurnal Ilmiah Akuntansi, 4(1), 102-114. Retrieved from: http://www.ejournal.pelitaindonesia.ac.id/ojs32/index.php/BILANCIA/article/view/ 597.

Yung, K., and Chen, C. (2018). Managerial Ability and Firm Risk-Taking Behavior. Review of Quantitative Finance and Accounting, 51(4), 1005-1032. doi: 10.1007/s11156-0170695-0. 
The Indonesian Journal of Accounting Research - Sep, Vol. 24, No.3, 2021

\section{Appendix}

Risk Management Framework Index ISO 31000

\begin{tabular}{|c|c|c|c|}
\hline No & Dimensions of Risk Manage ment & Code & Score \\
\hline \multicolumn{4}{|c|}{ A. Mandate and Commitment (3 Items) } \\
\hline 1 & $\begin{array}{l}\text { There is information about the company's commitment to carry out } \\
\text { risk management }\end{array}$ & A. 1 & 1 \\
\hline 2 & $\begin{array}{l}\text { There is a responsibility of the board of directors for risk } \\
\text { management }\end{array}$ & A. 2 & 1 \\
\hline 3 & $\begin{array}{l}\text { There is a responsibility of the board of commissioners to risk } \\
\text { management }\end{array}$ & A.3 & 1 \\
\hline \multicolumn{4}{|c|}{ B. Risk Management Framework Planning (13 Items) } \\
\hline 4 & There is a clear company vision and mission & B.4 & 1 \\
\hline 5 & There is information about the risk management policy & B.5 & 1 \\
\hline 6 & $\begin{array}{l}\text { Appointment of the party responsible for implementing risk } \\
\text { management }\end{array}$ & B.6 & 1 \\
\hline 7 & There is an internal control system & B.7 & 1 \\
\hline 8 & There is an internal audit charter & B. 8 & 1 \\
\hline 9 & There is a risk monitoring committee charter & B.9 & 1 \\
\hline 10 & There is environmental protection & B.10 & 1 \\
\hline \multirow[t]{2}{*}{11} & There is a guarantee of occupational safety and health & B.11 & 1 \\
\hline & $\begin{array}{l}\text { Establishme nt of Internal Communication Mechanism and } \\
\text { Reporting System: }\end{array}$ & & \\
\hline 12 & $\begin{array}{l}\text { Availability of sufficient annual risk management achievement } \\
\text { reports }\end{array}$ & B.12 & 1 \\
\hline 13 & Establishment of a corporate governance structure & B.13 & 1 \\
\hline \multirow[t]{2}{*}{14} & There is an organizational infrastructure & B.14 & 1 \\
\hline & $\begin{array}{l}\text { Establishme nt of External Communication Mechanism and } \\
\text { Reporting System: }\end{array}$ & & \\
\hline 15 & There is stakeholder analysis & B. 15 & 1 \\
\hline 16 & Compliance with applicable regulations & B.16 & 1 \\
\hline \multicolumn{4}{|c|}{ C. Application of Risk Management (4 Items) } \\
\hline 17 & There is a risk management framework & C.17 & 1 \\
\hline 18 & There is an internal risk division & C. 18 & 1 \\
\hline 19 & There is a division of external risks & C.19 & 1 \\
\hline 20 & There are risk mitigation treatments & C.20 & 1 \\
\hline \multicolumn{4}{|c|}{ D. Monitoring and Review of Risk Manage ment Framework (2 Items) } \\
\hline 21 & Monitoring of risk management by the board of commissioners & D.21 & 1 \\
\hline
\end{tabular}




\begin{tabular}{|c|l|c|c|}
\hline No & \multicolumn{1}{|c|}{ Dimensions of Risk Manage ment } & Code & Score \\
\hline 22 & $\begin{array}{l}\text { Independent third-party monitoring of both external and internal } \\
\text { audits }\end{array}$ & D.22 & 1 \\
\hline E. Improvement of the Continuous Risk Manage ment Framework (3 Items) \\
\hline 23 & Continuing education and training on risk management & E.23 & 1 \\
\hline 24 & Benchmarking & E.24 & 1 \\
\hline 25 & $\begin{array}{l}\text { There is the application of the PDCA (Plan Do Check Action) } \\
\text { principle }\end{array}$ & E.25 & 1 \\
\hline \multicolumn{2}{|c|}{ TOTAL } & $\mathbf{2 5}$ \\
\hline
\end{tabular}


The Indonesian Journal of Accounting Research - Sep, Vol. 24, No.3, 2021

\section{intentionally blank}

